\title{
Teaching Video NeuroImages: Palatal tremor associated with SPG7 variants
}

Guido Primiano, MD, Ginevra Zanni, MD, PhD, Marta Nardella, BS, PhD, and Serenella Servidei, MD Neurology ${ }^{\circledR}$ 2020;94:e2074-e2075. doi:10.1212/WNL.0000000000009409

Figure Brain MRI of patient with SPG7 variant and palatal tremor

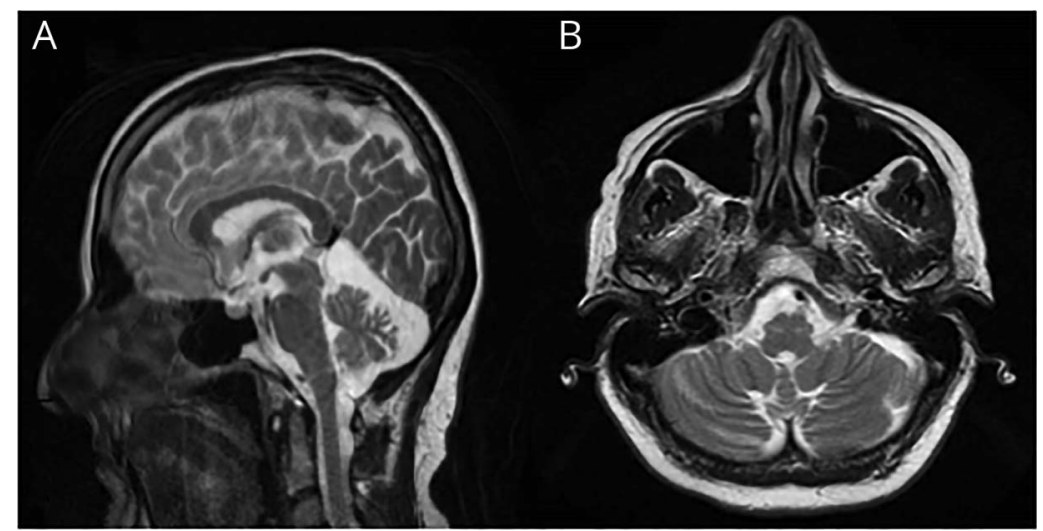

(A) Sagittal and (B) axial T2-weighted images show cerebellar atrophy but not enlarged olives.

A 58-year-old woman presented with a 30-year history of progressive ataxia, dysarthria, and bilateral leg spasticity. Neurologic examination revealed involuntary movement of the uvula and soft palate at $2-3 \mathrm{~Hz}$ (video). Brain MRI showed only cerebellar atrophy (figure). Targeted next-generation sequencing identified a pathogenic homozygous variant in the SPG7 gene (c.773_774delTG; p.V258Gfs*30) leading to the diagnosis of spastic paraplegia type 7. Palatal tremor may be present in a variety of acquired or familial disorders ${ }^{1}$ such as cerebrotendinous xanthomatosis, SCA20, POLG-related disorders, neuroferritinopathy, and Alexander disease, but it was reported in only one patient with SPG7 mutations. ${ }^{2}$ Our observation confirms that SPG7 screening should be considered in patients with palatal tremor and ataxia.

\section{Acknowledgment}

G.P and S.S. received support for activities related to this work from the ERN EURO-NMD.

\section{Study funding}

No targeted funding reported.

\section{Disclosure}

The authors report no disclosures relevant to the manuscript. Go to Neurology.org/ $\mathrm{N}$ for full disclosures.

\section{Correspondence}

Dr. Primiano

guido.primiano@gmail.com

\section{MORE ONLINE}

○ Video

\section{$\rightarrow$ Teaching slides}

links.lww.com/WNL/

B82

From the UOC Neurofisiopatologia (G.P., S.S.), Fondazione Policlinico Universitario A. Gemelli IRCCS; Istituto di Neurologia (G.P., S.S.), Università Cattolica del Sacro Cuore; and Unit of Neuromuscular and Neurodegenerative Disorders (G.Z., M.N.), Department of Neurosciences, IRCCS, Bambino Gesù Research Hospital, Rome, Italy.

Go to Neurology.org/N for full disclosures. 


\section{Appendix Authors}

\begin{tabular}{lll}
\hline Name & Location & Contribution \\
\hline $\begin{array}{l}\text { Guido } \\
\text { Primiano, } \\
\text { MD }\end{array}$ & $\begin{array}{l}\text { Fondazione Policlinico } \\
\text { Universitario A. Gemelli } \\
\text { IRCCS, Rome, Italy }\end{array}$ & $\begin{array}{l}\text { Designed and } \\
\text { conceptualized study, } \\
\text { analyzed the data, drafted } \\
\text { the manuscript }\end{array}$ \\
\hline $\begin{array}{l}\text { Ginevra } \\
\text { Zanni, } \\
\text { MD, PhD }\end{array}$ & Bambino Gesù Research & $\begin{array}{l}\text { Interpreted the data, revised } \\
\text { the manuscript for } \\
\text { intellectual content }\end{array}$ \\
\hline $\begin{array}{l}\text { Marta } \\
\text { Nardella, } \\
\text { BS, PhD }\end{array}$ & Bombino Italy & $\begin{array}{l}\text { Interpreted the data, revised } \\
\text { the manuscript for } \\
\text { intellectual content }\end{array}$ \\
\hline
\end{tabular}

Appendix (continued)

\begin{tabular}{|c|c|c|}
\hline Name & Location & Contribution \\
\hline $\begin{array}{l}\text { Serenella } \\
\text { Servidei, } \\
\text { MD }\end{array}$ & $\begin{array}{l}\text { Fondazione Policlinico } \\
\text { Universitario A. Gemelli } \\
\text { IRCCS, Rome, Italy }\end{array}$ & $\begin{array}{l}\text { Interpreted the data, revised } \\
\text { the manuscript for } \\
\text { intellectual content }\end{array}$ \\
\hline
\end{tabular}

\section{References}

1. Deuschl G, Wilms H. Clinical spectrum and physiology of palatal tremor. Mov Disord 2002;17(suppl 2):S63-S66.

2. Gass J, Blackburn PR, Jackson J, Macklin S, van Gerpen J, Atwal PS. Expanded phenotype in a patient with spastic paraplegia 7. Clin Case Rep 2017;5: 1620-1622. 


\section{Neurology}

\section{Teaching Video NeuroImages: Palatal tremor associated with $S P G 7$ variants Guido Primiano, Ginevra Zanni, Marta Nardella, et al.}

Neurology 2020;94;e2074-e2075 Published Online before print April 21, 2020 DOI 10.1212/WNL.0000000000009409

\section{This information is current as of April 21, 2020}

Updated Information \& Services

References

Subspecialty Collections

Permissions \& Licensing

Reprints including high resolution figures, can be found at: http://n.neurology.org/content/94/19/e2074.full

This article cites 2 articles, 0 of which you can access for free at: http://n.neurology.org/content/94/19/e2074.full\#ref-list-1

This article, along with others on similar topics, appears in the following collection(s):

Mitochondrial disorders

http://n.neurology.org/cgi/collection/mitochondrial_disorders Spinocerebellar ataxia

http://n.neurology.org/cgi/collection/spinocerebellar_ataxia

Information about reproducing this article in parts (figures,tables) or in its entirety can be found online at:

http://www.neurology.org/about/about_the_journal\#permissions

Information about ordering reprints can be found online:

http://n.neurology.org/subscribers/advertise

Neurology ${ }^{\circledR}$ is the official journal of the American Academy of Neurology. Published continuously since 1951 , it is now a weekly with 48 issues per year. Copyright @ 2020 American Academy of Neurology. All rights reserved. Print ISSN: 0028-3878. Online ISSN: 1526-632X.

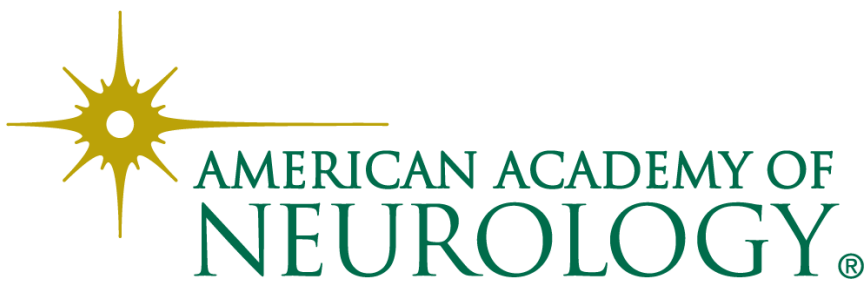

